\title{
PERANCANGAN SISTEM PENGONTROLAN STOK BARANG DENGAN METODE ECONOMIC ORDER QUANTITY (EOQ)
}

\author{
Rizka Adrifa ${ }^{1}$, Rahmad Kurniawan ${ }^{2}$, Amat Sofiyan ${ }^{3}$ \\ ${ }^{123}$ Sekolah Tinggi Manajemen Informatika Dan Komputer (STMIK) Dumai \\ Jl. Utama Karya, Bukit Batrem II, Dumai - Riau 28811 \\ e-mail : rizkaadrifa909@gmail.com
}

\begin{abstract}
ABSTRAK
Manajemen inventory atau persediaan sangat berkaitan erat dengan setiap perusahaan yang bergerak pada bidang penjualan .Namun banyak persediaan belum terencana dengan baik sehingga persediaan kurang optimal dan belum efektifnya pengontrolan stok dan pengorderan barang yang berjalan pada suatu perusahaan. Metode penelitian yang digunakan yaitu analisis kuantitatif dengan metode EOQ. Metode Economic Order Quantity ini digunakan untuk menentukan kuantitas pesanan persediaan yang dapat meminimalkan biaya penyimpanan dan biaya pemesanan persediaan, sehingga akan mengurangi biaya penyimpanan, penghematan ruang gudang dan ruangan kerja serta memperkecil risiko terjadinya kerusakan barang. Maka dengan aplikasi yang dibuat dapat dipergunakan sebaik mungkin untuk mencapai tingkat efisien dan efektif.
\end{abstract}

Kata kunci : pengontrolan stok, Economic order quantity (EOQ)

\section{PENDAHULUAN}

CV.Prima Jaya Motor merupakan salah satu perusahaan yang bergerak dibidang jual beli kendaraan bermotor secara tunai maupun kredit. CV. Prima Jaya Motor kegiatan utamanya menjual kendaraan bermotor. Namun persediaan kendaraan bermotor belum terencana dengan baik sehingga persediaan di toko kurang optimal, belum efektifnya pengontrolan stok dan pengorderan barang (kendaraan bermotor) yang berjalan pada CV. Prima Jaya Motor. Hal tersebut terlihat pada saat CV. Prima Jaya Motor mendapatkan pesanan produk kendaraan bermotor tertentu, barulah melakukan pemesanan. Sehingga para pembeli harus menunggu barang tersebut datang. Disisi lain juga pernah mengalami kelebihan persediaan, sehingga biaya penyimpanan yang meliputi biaya pemeliharaan dan biaya yang terjadi sehubungan dengan kerusakan barang yang disimpan dalam gudang.

Belum adanya penerapan metode Economic Order Quantity (EOQ) dalam control stock dan order barang pada CV.Prima Jaya Motor. Apabila persediaan barang dagangan yang dimiliki perusahaan kurang dari yang dibutuhkan maka proses kelancaran perdagangan akan terganggu.

Dari permasalahan diatas maka dirancanglah sebuah aplikasi terkomputerisasi pengontrolan stok dan pengorderan barang dengan metode Economic Order Quantity (EOQ) untuk memudahkan staff dalam melakukan control stock dan order barang, sehingga akan mengurangi biaya penyimpanan, penghematan ruang gudang dan ruangan kerja serta memperkecil risiko terjadinya kerusakan barang.

Dengan adanya perancangan sistem pengontrolan stok barang pada CV.Prima Jaya Motor ini dibuat dengan metode Economic Order Quantity (EOQ), maka diperkirakan akan meminimalkan biaya pemesanan barang dan kelebihan stok barang sehingga dapat menambah laba perusahaan.

\section{a. Pengertian Sistem}

Sistem merupakan kumpulan elemen yang saling berkaitan yang bertanggung jawab memproses masukan (input) sehigga menghasilkan keluaran (output).(Kusrini, 2007b)

Sistem merupakan sekumpulan objekobjek yang saling berelasi dan berinteraksi hubungan antar objek bisa dilihat sebagai satu 
I N F O R M A I I A

Jurnal Informatika, Manajemen dan Komputer, Vol. 10 No. 1, MEI 2018

eISSN : 2580-3042

pISSN : 1979-0694

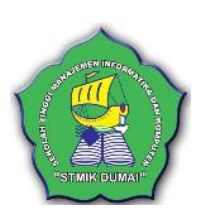

kesatuan dirancang untuk mencapai satu tujuan.(Hanif AL Fatta, 2007)

Untuk memahami sistem maka perlu membedakan unsur - unsur dari sistem yang membentuknya.

Berikut adalah karakteristik sistem dapat membedakan suatu sistem dengan sistem lainya(Hanif AL Fatta, 2007):

a. Batasan (Boundary) : Penggambaran dari suatu elemen atau unsur mana yang termasuk di dalam sistem dan yang di luar sistem.

b. Lingkungan (environment) : Segala sesuatu di luar sistem, lingkungan yang menyediakan asumsi, kendala, dan input terhadap suatu sistem.

c. Masukan (input) : Sumber daya (data, bahan baku, peralatan, energi ) dari lingkungan yang dikomsumsi dan dimanipulasi oleh suatu sistem.

d. Keluaran (output) : Sumber daya atau produk (informasi, laporan, dokumen, tampilan layar komputer, barang jadi) yang disediakan untuk lingkungan sistem oleh kegiatan dalam suatu sistem.

e. Komponen (component) : Kegiatan-kegiatan atau proses dalam suatu sistem yang mentransformasikan input menjadi bentuk setengah jadi, Komponen ini bisa merupakan subsistem dari sebuah sistem.

f. Penghubung (interface) : Tempat dimana komponen atau sistem dan lingkungannya bertemu atau berinteraksi,

g. Penyimpanan (storage) : Area yang dikuasai dan digunakan untuk penyimpanan sementara dan tetap dari informasi, energi, bahan baku, dan sebagainya. Penyimpanan merupakan suatu media penyangga diantara komponen tersebut bekerja dengan berbagai tingkatan yang ada dan memungkinkan komponen yang berbeda dari berbagai data yang sama.

\section{b. Sistem manajemen database}

Sistem manajemen database (database management system/DBMS). Semua DBMS memiliki suatu pengolahan bahasa deskripsi data (data deskription language processor) yang digunakan untuk menciptakan database serta suatu pengolahan database yang menyedikan isi database bagi pemakai.(Tata Sutabri, 2014)

\section{c. Pengertian Perancangan Sistem}

Untuk melakukan perancangan sistem, dibutuhkan alat bantu perancangan. Dalam perancangan pada tahap ini pengembangan sistem bisa menentukan arsitektur sistemnya,

merancang gambaran konseptual sistem, merancang database, perancangan interface, hingga membuat flowchart program.(Adi Nugroho, 2011)

\section{d. Pengetian Entity Realition Diagram (ERD)}

Pengertian ERD adalah sebuah pendekatan Top-bottom dalam perancangan basis data yang dimulai dengan mengidentifikasikan data-data terpenting yang disebut entitas.(Indrajani, 2015)

\section{e. Pengertian Data Flow Diagram (DFD)}

DFD adalah suatu model logika atau proses yang dibuat untuk menggambarkan asal data dan tujuan data yang keluar dari sistem, tempat penyimpanan data, proses apa yang menghasilkan data tersebut, serta interaksi antara data yang tersimpan dan proses yang dikenakan pada data tersebut.(Kusrini, 2007a)

\section{f. Context Diagram}

Context diagram atau diagram context adalah sebuah diagram sederhana yang menggambarkan hubungan antara entiti luar, masukan, dan keluaran dari sebuah sistem. Diagram Context direpresentasikan dengan lingkaran tunggal yang mewakili keseluruhan dari sebuah sistem(Andri Kristanto, 2007)

\section{g. Bagan Alir Program (Program Flowchart)}

Bagan alir (flowchart) adalah penggambaran secara grafik dari langkah-langkah dan urutan prosedur suatu program. Biasanya mempermudah penyelesaian masalah, khususnya yang perlu dipelajari dan dievaluasi lebih lanjut.(Indrajani, 2015)

\section{h. Manajemen Persediaan}

Inventory atau Persediaan adalah suatu teknik untuk manajemen material yang berkaitan dengan persediaan. Manajemen material dalam inventory dilakukan dengan beberapa input yang digunakan yaitu: permintaan yang terjadi (demand) dan biaya-biaya yang terkait dengan penyimpanan, serta biaya apabila terjadi kekurangan persediaan(shortage).(Agus

Ristanto, 2014)

\section{i. Defenisi Metode Economic Order Quantity (EOQ)}

Economic Order Quantity (EOQ) merupakan salah satu model manajemen persediaan, model EOQ digunakan untuk menentukan kuantitas pesanan persediaan yang 
I N F O R M A I I A

Jurnal Informatika, Manajemen dan Komputer, Vol. 10 No. 1, MEI 2018

elSSN : 2580-3042

pISSN : 1979-0694

dapat meminimalkan biaya penyimpanan dan biaya pemesanan persediaan. Eoq adalah jumlah kuantitas barang yang dapat diperoleh dengan biaya yang minimal. Analisis yang digunakan terdiri dari(Agus Ristanto, 2014):

1. Rumus untuk mengetahui EOQ penulis menggunakan:

$\mathrm{EOQ}=\frac{\sqrt{2 \cdot D . S}}{C}$

2. Rumus untuk mengetahui Frekuensi Pemesanan dapat dihitung dengan:

$(\mathrm{F})=\frac{D}{E O Q}$

3. Rumus untuk mengetahui total biaya pemesanan dapat dihitung dengan:

$$
(\mathrm{TOC})=\left(\frac{D}{E O Q}\right) \cdot S
$$

4. Rumus untuk mengetahui total biaya penyimpanan dapat dihitung dengan:

$$
(\mathrm{TCC})=\left(\frac{E O Q}{2}\right) \cdot C
$$

5. Rumus biaya total persediaan dapat dihitung dengan:

\section{$(\mathrm{TC})=$ TOC $+\mathrm{TCC}$}

6. Rumus untuk mengetahui jumlah permintaan per hari dapat dihitung dengan:

$$
\text { (d) }=\frac{D}{\text { Jumlah hari kerja }}
$$

7. Rumus untuk mengetahui jumlah pesanan selama Lead Time adalah:

$$
\text { (R) }=\mathrm{d} \times \mathrm{L}
$$

8. Rumus ROP dapat diketahui dengan menggunakan:

$$
(\mathrm{ROP})=\mathrm{D} / 365 \times \text { lead time }
$$

9. Rumus untuk mengetahui biaya pembelian menggunakan:

Biaya Pembelian = EOQ $\times \mathrm{P}$

10. Rumus untuk mengetahui jumlah maksimal persediaan (MS) dengan:

$M S=\mathrm{Ss}+\mathrm{EOQ}$

Dimana:

$\begin{array}{lll}\text { EOQ } & =\text { Jumlah pemesanan ekonomis } \\ \mathrm{F} & =\text { Frekuensi pemasaran } & \\ \mathrm{TCC} & =\text { Total biaya penyimpanan } & \\ \mathrm{Ss} & =\text { Safety stock } & \\ \mathrm{TC} & =\text { Total biaya persediaan } & \\ \mathrm{T} & =\text { Waktu pemesanan } & \\ \mathrm{P} & =\text { Harga barang per unit } & \\ \mathrm{L} & =\text { Lead time } & \\ \mathrm{d} & =\text { Jumlah permintaan per hari } & \\ \mathrm{C} & =\text { Biaya penyimpanan } & \\ \mathrm{S} & =\text { Biaya melakukan } \\ & \text { pemesanan/barang } & \\ \mathrm{D} & =\text { Jumlah permintann } & \text { selama } \\ & \text { periode/tahun } & \end{array}$

\section{j. Asumsi Model EOQ}

Dalam penentuan model EOQ terdapat beberapa asumsi-asumsi, diantaranya adalah :

- Jumlah kebutuhan bahan baku sudah dapat ditentukan terlebih dahulu secara pasti untuk penggunaan satu tahun atau satu periode.

- Penggunaan bahan baku relatif stabil dalam satu tahun atau satu periode.

- Harga bahan baku konstan selama periode tertentu.

Lead Time tetap dan tidak terjadi stockout(Syaparuddin Harahap \& Naleni Indra, n.d.)

\section{k. Pengertian Visual Basic}

Visual Basic merupakan turunan bahasa pemograman BASIC dan menawarkan pengembangan perangkat lunak komputer berbasis grafik dengan cepat. Beberapa bahasa skrip seperti Visual Basic For Aplications (VBA) dan Visual Basic Scripting Edition (VBScript), mirip seperti halnya Visual Basic, tetapi cara kerjanya yang berbeda.(Muhammad Sadeli, 2012)

\section{METODOLOGI PENELITIAN}

Adapun metode penelitian yang dilakukan dalam menulis jurnal ini adalah :

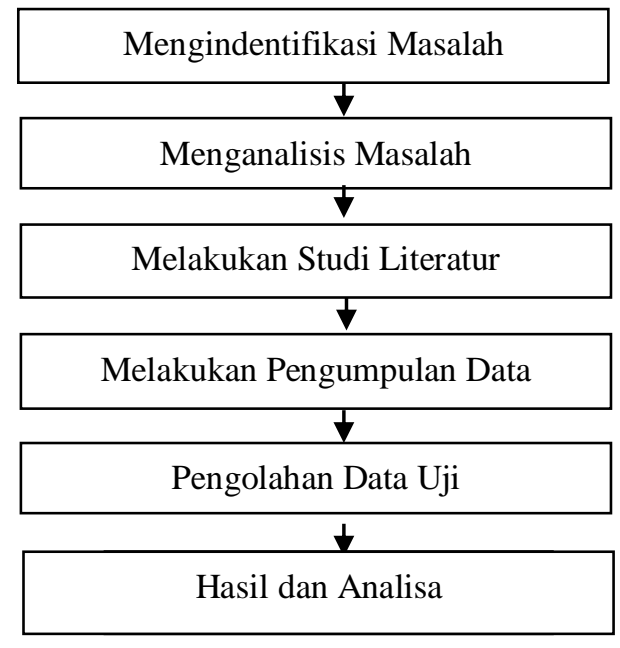

Gambar1.Kerja Penelitian

Berikut merupakan urutan-urutan langkah kerja berdasarkan gambar 1 ialah sebagai berikut :

1. Mengidentifikasi Masalah

Identifikasi masalah dalam penelitian ini ialah perancangan Sistem pengontrolan stok barang pada CV.Prima Jaya Motor dengan menggunakan metode Economic Order Quantity 
I N F O R M A I I A

Jurnal Informatika, Manajemen dan Komputer, Vol. 10 No. 1, MEI 2018

eISSN : 2580-3042

pISSN : 1979-0694

(EOQ). Banyaknya permasalahan persediaan pada perusahaan tersebut sehingga pada saat menangani pengorderan dan pengontrolan stok barang banyak terjadi masalah. Melihat permasalahan yang ada pada CV.Prima Jaya Motor maka staff memerlukan aplikasi dan metode yang baru untuk mempermudah staff dalam menyusun laporan agar lebih efekti dan efisien.

2. Menganalisa Masalah

Analisis masalah pada penelitian ini dilakukan dengan dua metode yaitu metode deskriptif dan metode komperatif serta penelitian laboratorium .

3. Melakukan Literatur

Studi pustaka dilakukan dengan tujuan untuk mengetahui metode apa yang akan digunakan untuk menyelesaikan permasalahan yang akan diteliti, serta mendapatkan dasar-dasar referensi yang kuat bagi peneliti dalam menerapkan suatu metode yang digunakannya.

4. Mengumpulkan data

Metode pengumpulan data dilakukan dengan cara melakukan pengamatan langsung ke CV.Prima Jaya Motor. Selain pengamatan, juga dilakukan wawancara kepada pihak-pihak yang terkait dengan penelitian ini khususnya pada bagian penjualan, sekaligus pengambilan data tuk acuan rinci skripsi.

5. Pengolahan Data Uji

Pada tahap ini hasil dari analisis diperiksa kembali atau diuji lagi menggunakan bahasa pemograman Visual Basic 6.0.Sistem yang dipakai saat ini adalah secara pengentrian secara manual.

6. Hasil dan Analisa

Setelah melakukan pengujian dengan bahasa pemograman Visual Basic 6.0 maka didapat hasil analisis dengan pengetahuan baru. Hasil analisa yang telah dilakukan akan dijadikan data baru untuk diperiksa serta menjadikan hasil tesebut sebagai bahan pertimbangan staff apakah akan melakukan peningkatan dalam pengotrolan stok barang.

\section{HASIL DAN PEMBAHASAN}

a. Aliran Sistem Informasi Baru

Aliran sistem informasi yang baru pada CV. Prima Jaya Motor tidak jauh berbeda dengan aliran sistem informasi yang lama atau yang sedang berjalan, hanya saja pada aliran sistem informasi baru sudah menggunakan

penyimpanan sistem database sehingga dalam proses pembuatan laporan dapat dilakukan dengan cepat dan akurat sehingga lebih efektif dan efisien. Dapat dilihat pada gambar 2.

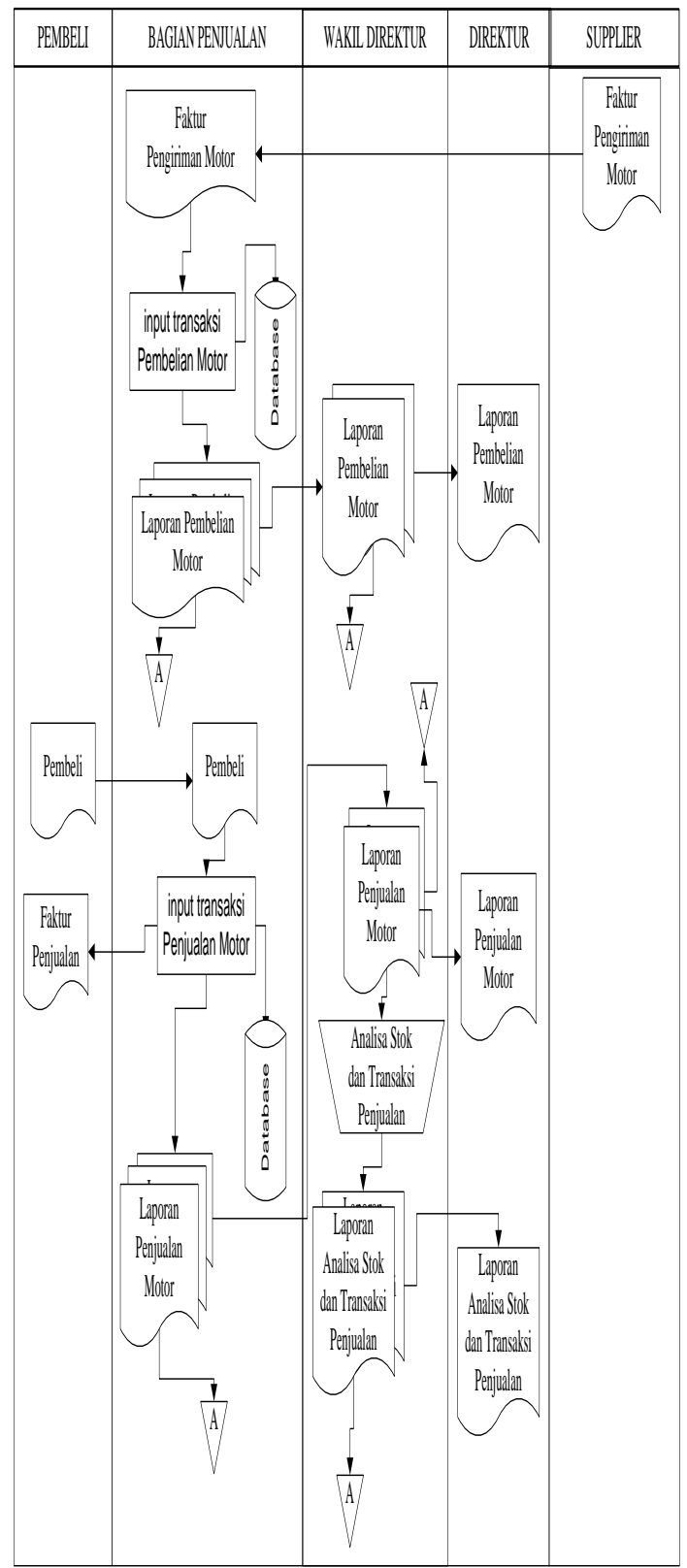

Gambar 2. Aliran Sistem Informasi Baru

\section{b. Context Diagram}


I N F O RM A T I A

Jurnal Informatika, Manajemen dan Komputer, Vol. 10 No. 1, MEI 2018

eISSN : 2580-3042

pISSN : 1979-0694

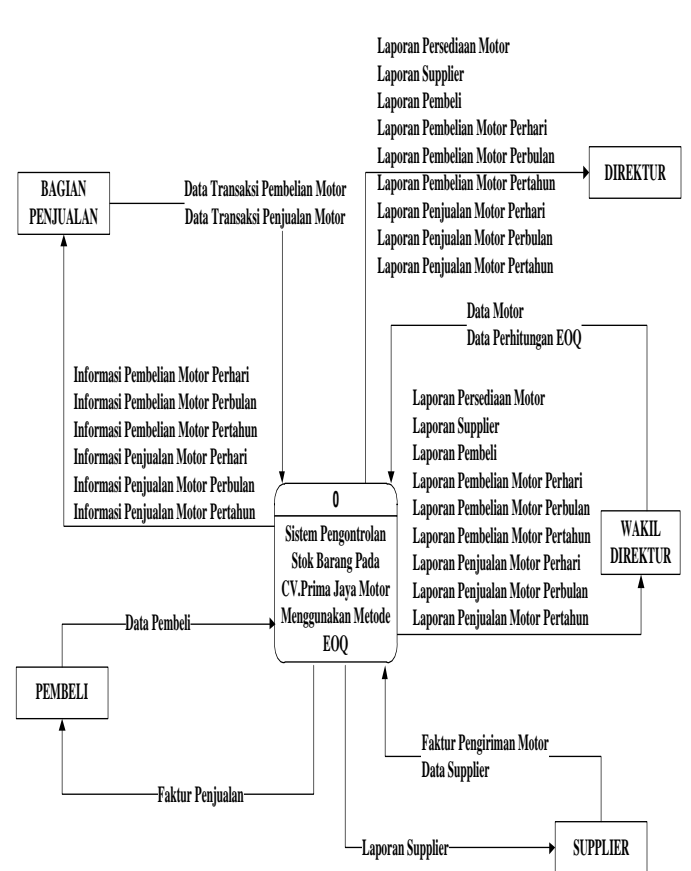

Gambar 3. Context Diagram

\section{c. Data Flow Diagram}

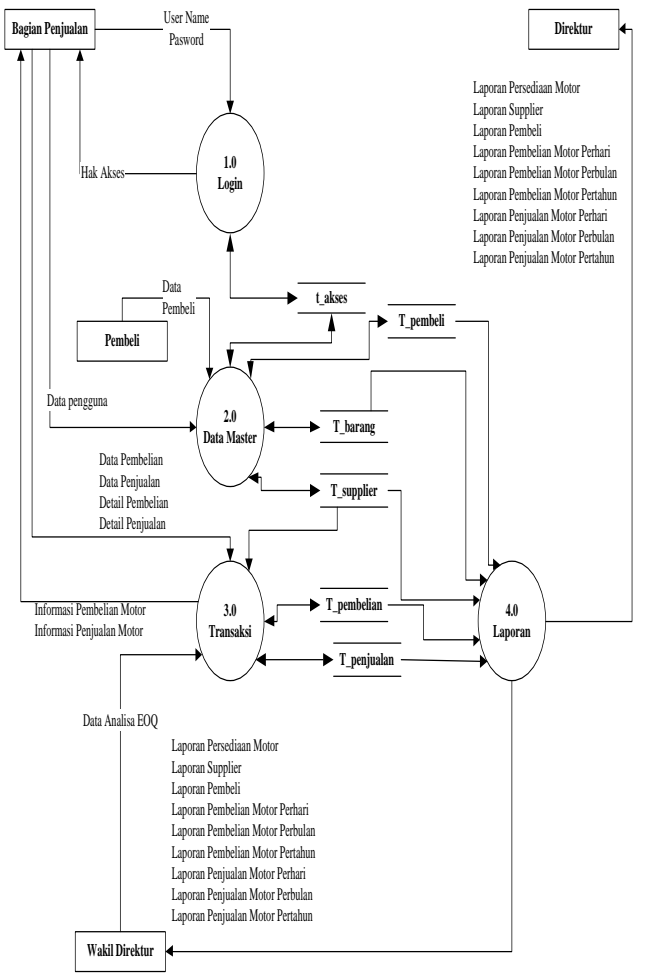

Gambar 4. Data Flow Diagram

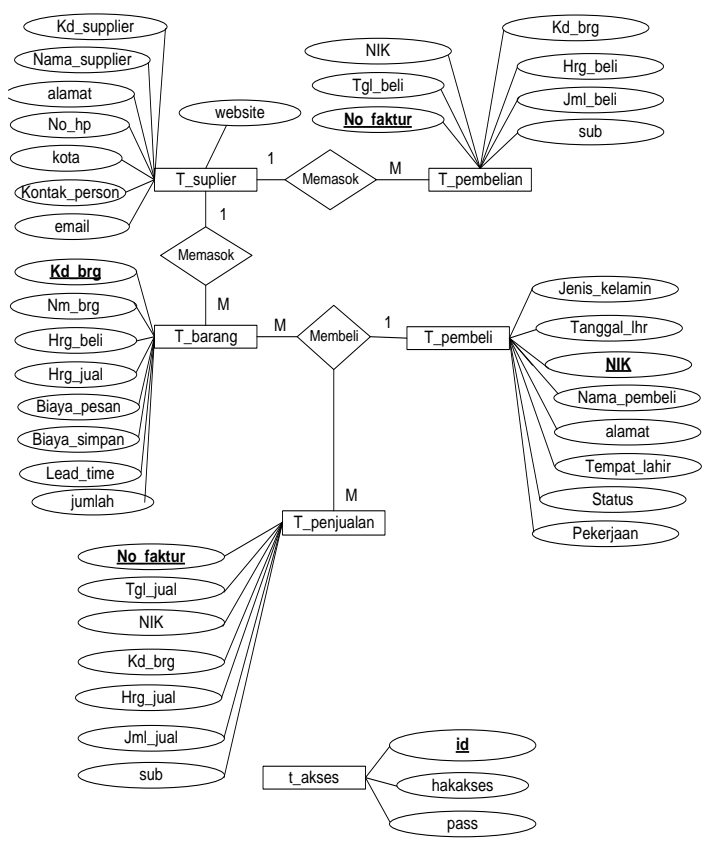

Gambar 5. ERD (Entity Relationship Diagram)

\section{e. Form Input Data Motor}

Pada form input Data Motor ini digunakan untuk melakukan penginputan data Motor

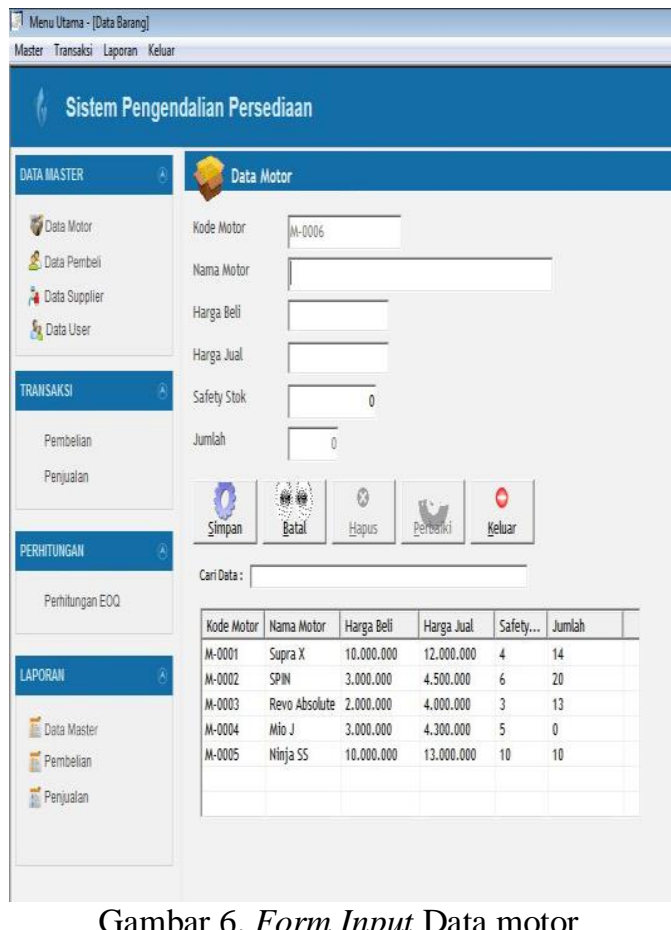

Gambar 6. Form Input Data motor

f. Form Input Data Pembeli 
INFORMA T I A

Jurnal Informatika, Manajemen dan Komputer, Vol. 10 No. 1, MEI 2018

elSSN : 2580-3042

pISSN : 1979-0694

Pada form input Data Pembeli ini digunakan untuk melakukan penginputan data Pembeli

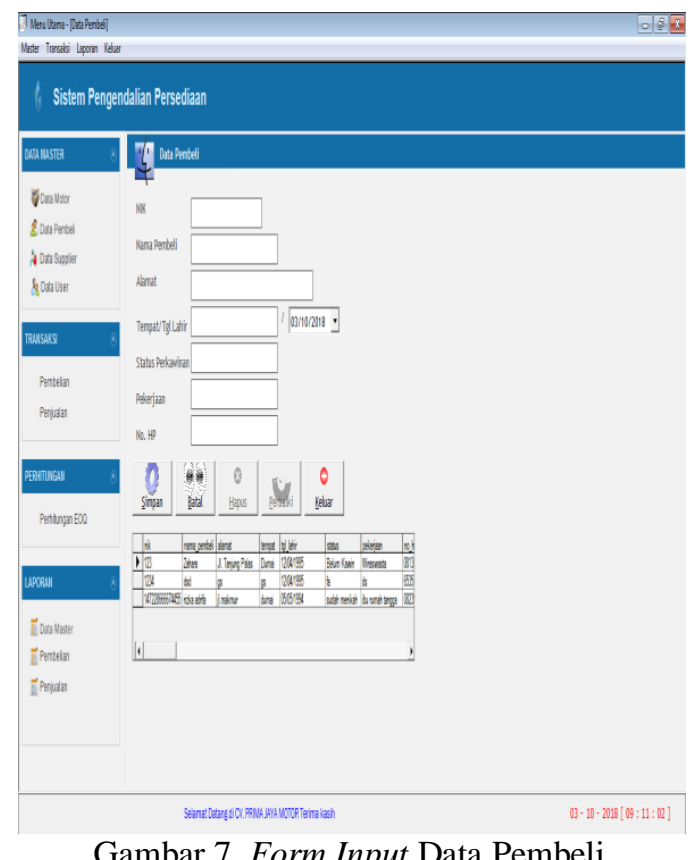

Gambar 7. Form Input Data Pembeli

\section{g. Form Input Data Supplier}

Pada form input Data Supplier ini digunakan untuk melakukan penginputan data Supplier [7 Menulans- [Dats Supplie]

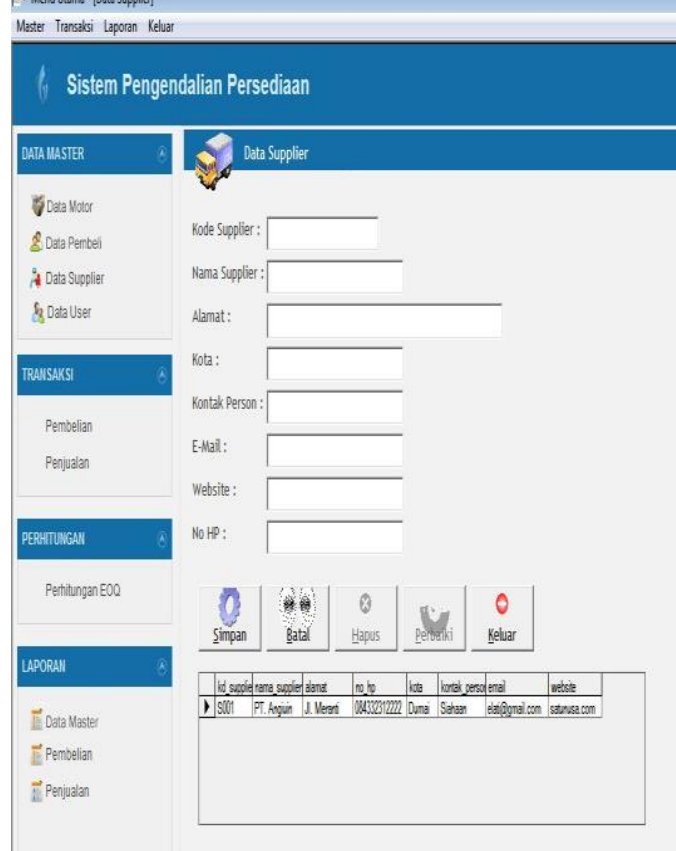

Gambar 8. Form Input Data Supplier

\section{h. Form Input Pengguna}

Pada form input Data Pengguna (User) ini digunakan untuk melakukan penginputan data Pengguna

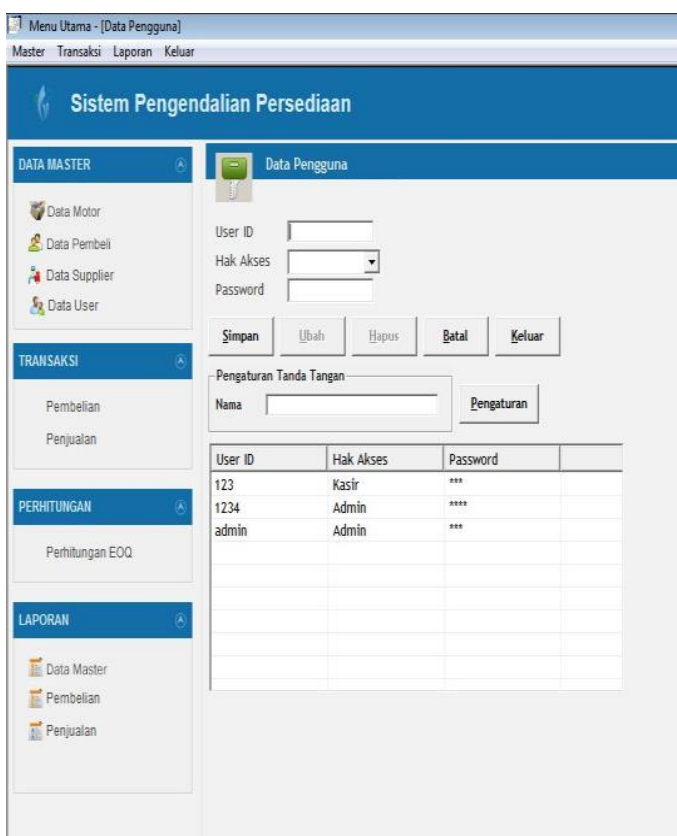

Gambar 9. Form Input Pengguna

\section{i. Form Transaksi Pembelian}

Pada form ini digunakan untuk melakukan penginputan barang yang akan dibeli ke supplier

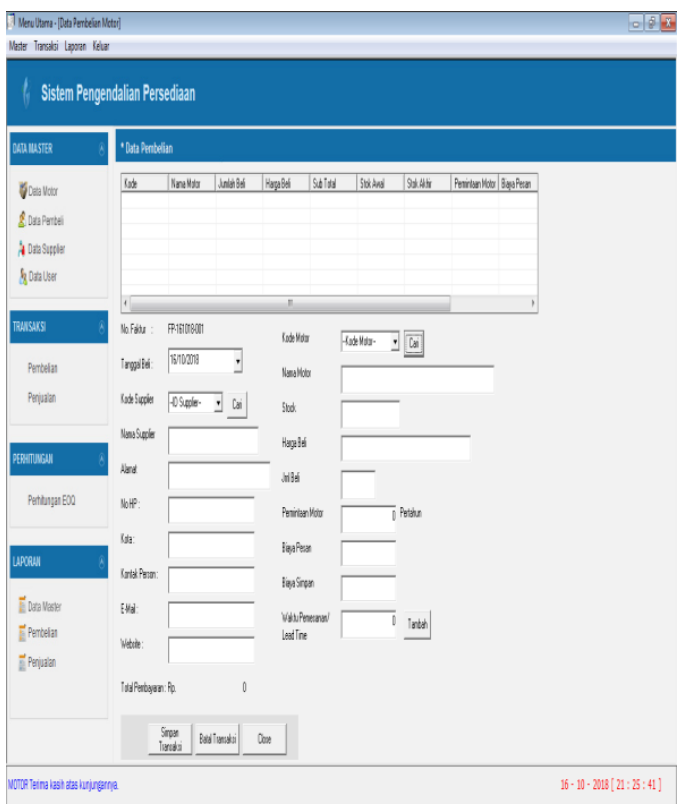

Gambar 10. Form Transaksi Pembelian 
IN F ORM A T I R

Jurnal Informatika, Manajemen dan Komputer, Vol. 10 No. 1, MEI 2018

elSSN : 2580-3042

pISSN : 1979-0694

\section{j. Form Transaksi Penjualan}

Pada form ini digunakan untuk menginput data transaksi penjualan

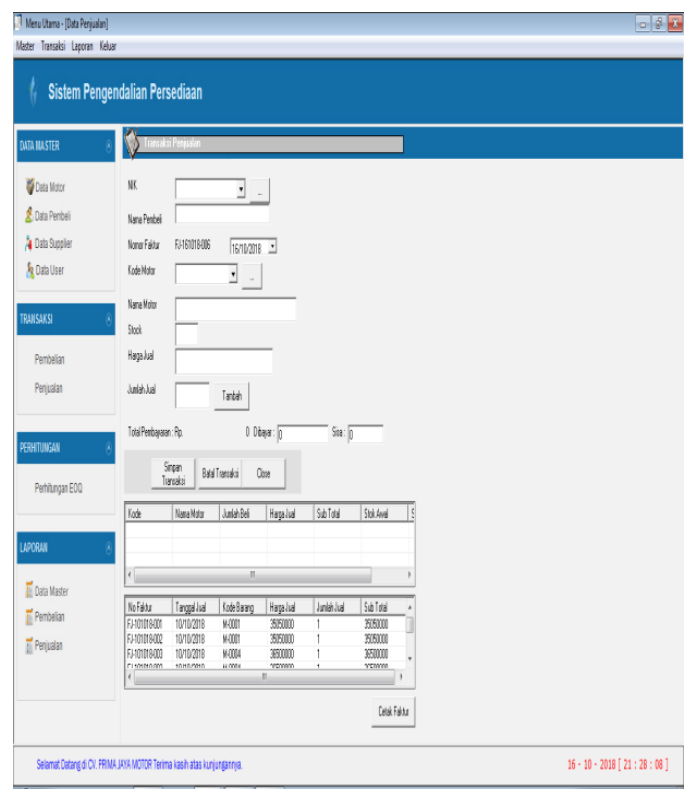

Gambar 11. Form Transaksi Penjualan

\section{k. Form Perhitungan EOQ}

Pada form ini digunakan untuk melakukan perhitungan EOQ nya.

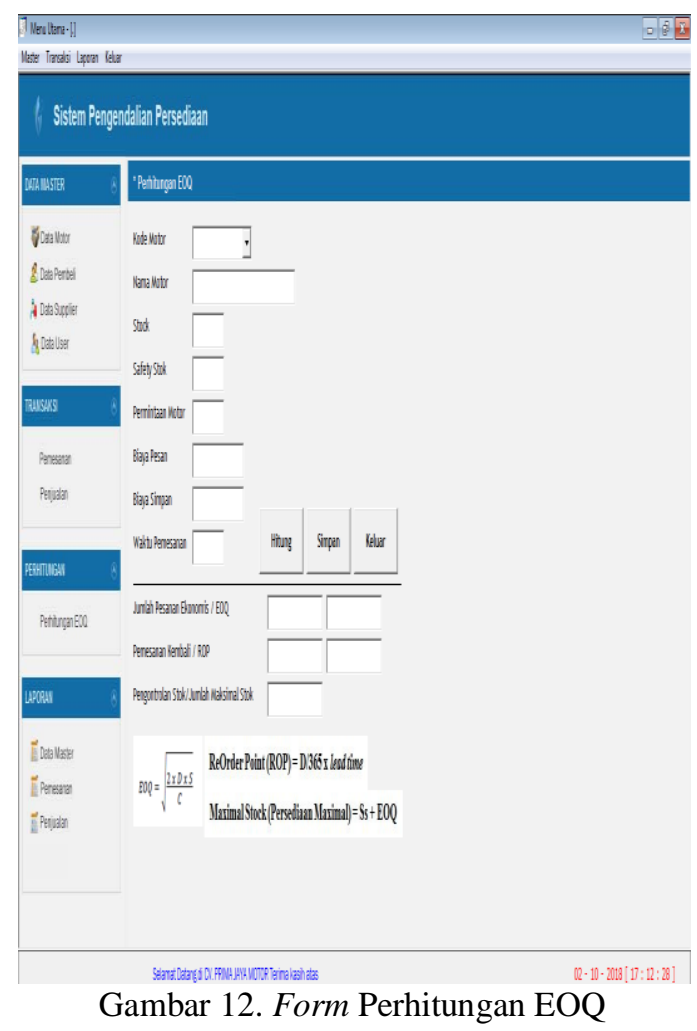

\section{l. Form Laporan Data Master}

Pada form laporan ini pengguna dapat menampilkan laporan data master barang dan supplier.

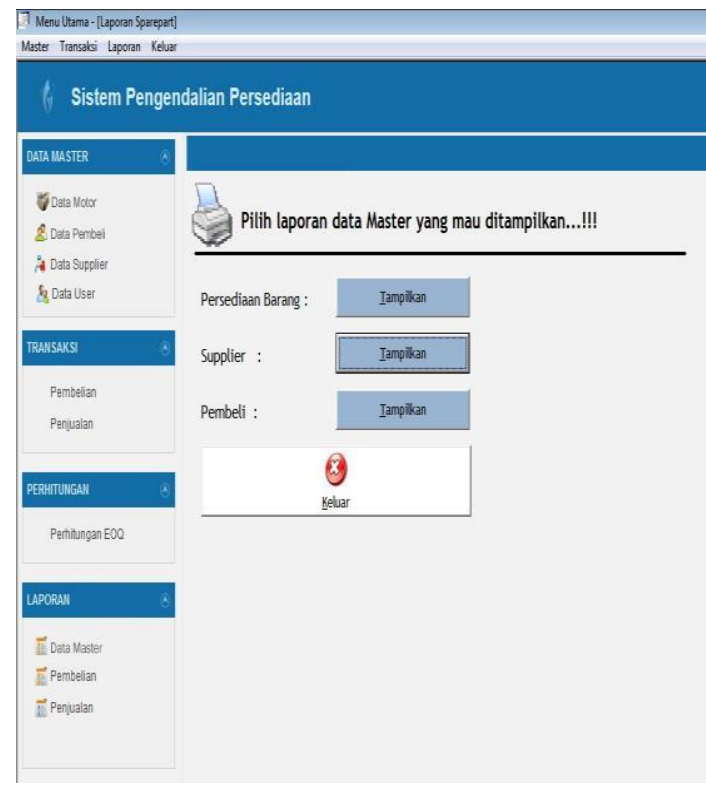

Gambar 13. Form Laporan Data Master

m. Form Laporan Data Transaksi Pembelian

Pada form laporan ini pengguna dapat menampilkan laporan data transaksi pembelian.

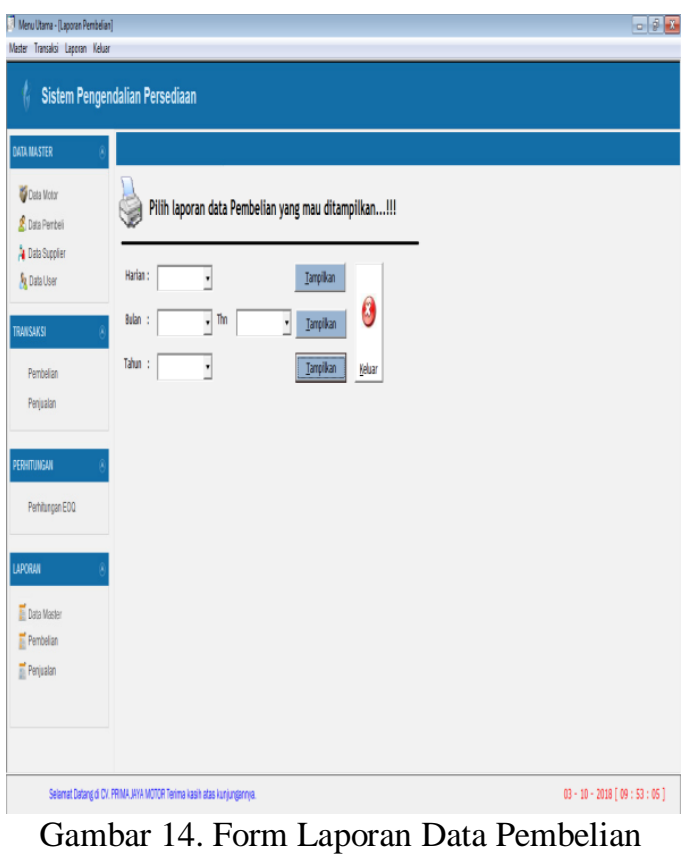


IN F ORM A T I R

Jurnal Informatika, Manajemen dan Komputer, Vol. 10 No. 1, MEI 2018

eISSN : 2580-3042

pISSN : 1979-0694

n. Form Laporan Data Transaksi Penjualan

Pada form laporan ini pengguna dapat menampilkan laporan data penjualan.

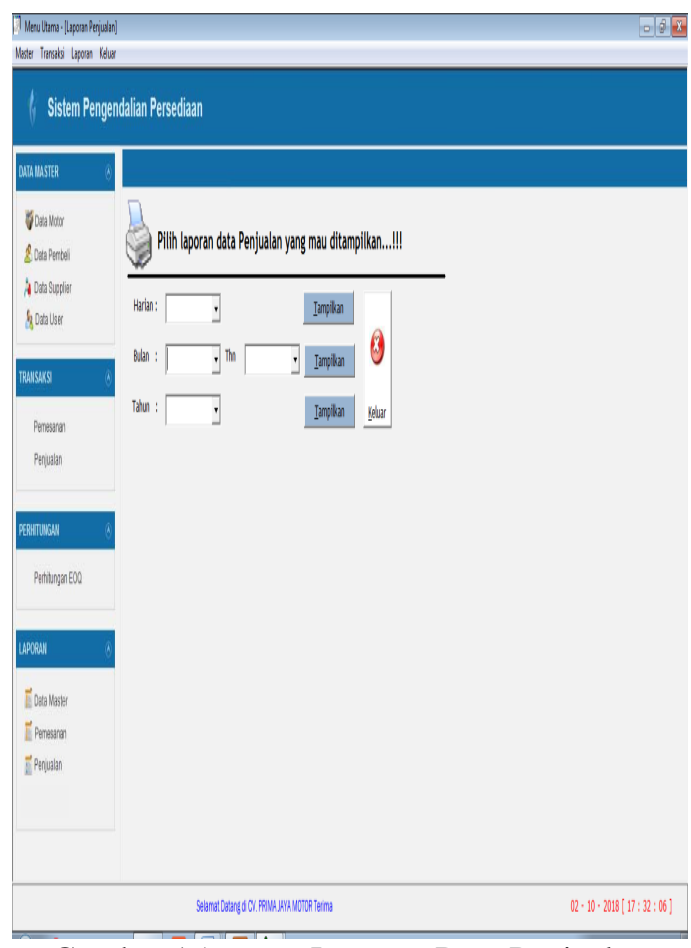

Gambar 15. Form Laporan Data Penjualan

o. Laporan Persediaan Motor

Laporan persedian motor yang berisi persedian data motor yang ada.

\section{CV.PRIMAJAYA MIOTOR}

J. Cempedak Hp, 085665999975 Dumai- Riau

LAPORAI PERSEDLAN BARAIG

\begin{tabular}{|c|c|c|c|c|c|c|}
\hline 10 & Irdel Iotor & Iam Illotor & Siak & Hurgabeli & \multicolumn{2}{|c|}{ Hurąilul } \\
\hline 1 & WOOOI & Svpra X & II & Ro 1000000 & Rp & 12000000 \\
\hline ! & MODOL & SPN & D & $R_{p} \quad 3,00000$ & lp & 450000 \\
\hline 3 & MOOOS & Rero Absodute & 13 & Ro $\quad 200000$ & lp & 400000 \\
\hline 4 & MOOWH & W5ol & 0 & Rp $\quad 3: 00000$ & lp & 430.000 \\
\hline$j$ & MEOOS & SiriaSS & 10 & Ro $\quad 10000000$ & Ip & 13000000 \\
\hline
\end{tabular}

Dumi.8S Septeaber1018

Jengetabi,

Gambar 16. Laporan Persediaan Motor

\section{p. Laporan Pembeli}

Laporan pembeli yaitu laporan yang berisi nama pembeli yang ada.
C.PRNIADHA HOOTOR

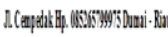

\begin{tabular}{|c|c|c|c|c|c|c|c|}
\hline \multicolumn{8}{|c|}{ 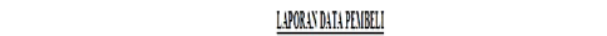 } \\
\hline Vi. 17 & Surlatide & than: & Ilapt & linglatit & Sinfetain & Ptapin & Sall \\
\hline$y$ & in & 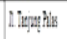 & Dai & DAF & Bisals & Tanas & mibegen \\
\hline$y$ & $\$$ & (1) & 1 & LAM & i & th & 68 \\
\hline
\end{tabular}

Gambar 17. Laporan Pembeli

\section{q. Laporan Supplier}

Laporan supplier yaitu laporan yang berisi nama supplier yang ada.

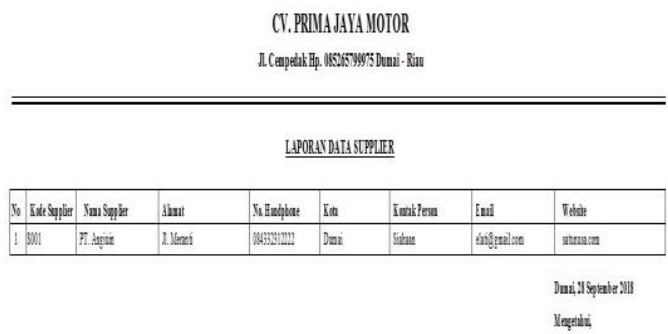

Gambar 18. Laporan Supplier

r. Laporan Data Pembelian Perhari

Laporan data pembelian perhari yaitu laporan yang berisi data setiap pembelian dalam satu hari.

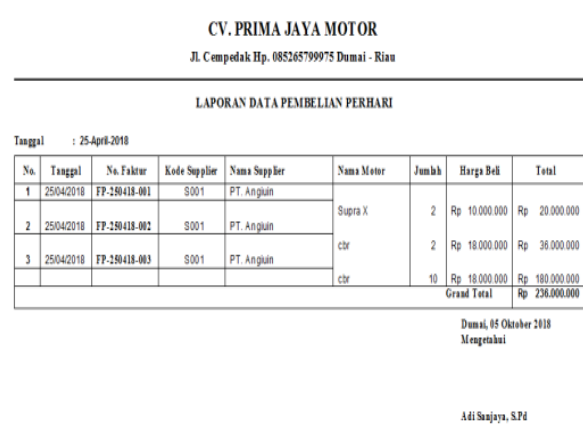

Gambar 19. Laporan Data Pembelian Perhari

\section{s. Laporan Data Pembelian Perbulan}

Laporan data pembelian perbulan yaitu laporan yang berisi data setiap pembelian perbulan. 
IN F ORM A T I R

Jurnal Informatika, Manajemen dan Komputer, Vol. 10 No. 1, MEI 2018

elSSN : 2580-3042

pISSN : 1979-0694

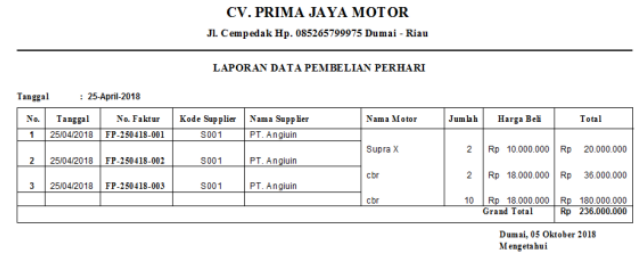

Gambar 20. Laporan Data Pembelian Perbulan

\section{t. Laporan Data Pembelian PerTahun}

Laporan data pembelian pertahun yaitu laporan yang berisi data setiap pembelian dalam satu tahun.

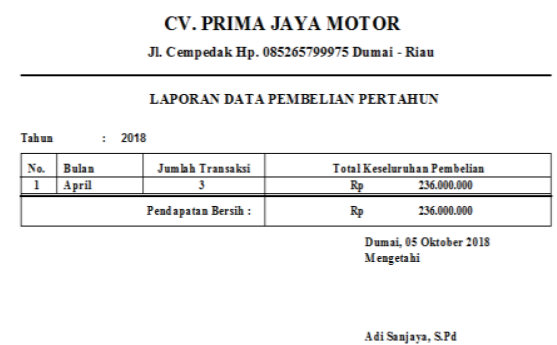

Gambar 21. Laporan Data Pembelian PerTahun

\section{KESIMPULAN}

Maka berdasarkan uraian-uraian di atas dan perancangan sistem yang dimaksud tersebut di dalam jurnal ini, maka dapat diambil beberapa kesimpulan :

1. Dengan menggunakan suatu sistem yang telah terkomputerisasi, maka akan mempermudah karyawan untuk melakukan pengontrolan stock barang dan pembuatan laporan yang akan di butuhkan perusahaaan.

2. Sistem komputerisasi pengontrolan stock barang dengan pemrograman Visual Basic ini adalah salah satu sistem yang dapat dipergunakan sebaik mungkin untuk mencapai tingkat efisien dan efektif dalam setiap proses pengolahan data, khususnyadalam mengontrol stock barang dibandingkan dengan menggunakan metode yang digunakan selama ini.

3. Penyimpanan data akan lebih aman dan lebih ekonomis, didukung lagi dengan layanan pencarian data yang dapat memberikan kemudahan, kecepatan dan ketepatan yang lebih baik.

\section{REFERENSI}

Adi Nugroho. (2011). Perancangan Dan Implementasi Sistem Basis Data. Yogyakarta: Andi.

Agus Ristanto. (2014). Manajemen persediaan. Yogyakarta: Graha Ilmu.

Andri Kristanto. (2007). Perancangan Sistem Informasi Dan Aplikasinya. Yogyakarta: Gavamedia.

Elwani. (2017). Penentuan Aturan Asosiasi Pada Transaksi Peminjaman Buku Menggunakan Algoritma FP-GROWTH, 9(1), 15-25.

Fauzansyah. (2017). Implementasi Algoritma KMeans Clustering Untuk Menentukan Arketipe Pembelian Suku Cadang Dan Asesoris Komputer(Studi Kasus Di Toko Laksamana Komputer Dumai). Jurnal Informatika, Manajemen Dan Komputer, 9(1), 26-35. Retrieved from http://www.ejournal.stmikdumai.ac.id/inde x.php/path/article/view/60

Hanif AL Fatta. (2007). Analisis \& Perancangan Sistem Informasi. Yogyakarta: Andi.

Indrajani. (2015). Database Design. Jakarta: Kompas Gramedia.

Kusrini. (2007a). Kosep Dan Aplikasi Sistem Pendukung Keputusan. Yogyakarta: Andi.

Kusrini. (2007b). Sistem Perancangan Dan Penglolaan Basis Data. Yogyakarta: Andi.

Muhammad Sadeli. (2012). Aplikasi Sms Dengan Visual Basic 6.0 Dan Visual Basic 2010. Jakarta: Maxicom.

Syaparuddin Harahap, \& Naleni Indra. (n.d.). Analisa Perancangan Dan Pengawasan Persedian Barang Dagangan Dengan Metode Economic Order Quantity (EOQ) Pada PT.Fastfood Indonesia Cabang Medan.

Tata Sutabri. (2014). Pengantar Teknologi Informasi. Yogyakarta: Andi. 